International Journal of Economics, Business and Accounting Research (IJEBAR)

Peer Reviewed - International Journal

Vol-4, Issue-1, 2020 (IJEBAR)

E-ISSN: 2614-1280 P-ISSN 2622-4771

https://jurnal.stie-aas.ac.id/index.php/IJEBAR

\title{
EMPLOYEE PERFORMANCE IN PT BPD KALTIM KALTARA SAMARINDA
}

\author{
Nabila Nur Fajrina ${ }^{1 *}$, Theresia Militina ${ }^{2}$, Gusti Noorlitaria Achmad ${ }^{3}$ \\ Master of Management Program Faculty of Economics and Business \\ Mulawarman University Samarinda (75117) Indonesia \\ EmaiL: nabilafajrin241@gmail.com
}

\begin{abstract}
In this study involving PT BPD Kaltim Kaltara Samarinda. In this study, to see the performance of employees used a sample of 162 respondents, based on the results of the questionnaire that has been distributed, it can be seen that the number of respondents to be analyzed was 162 respondents. The data analysis used by the author is the Structural Equation Model (SEM). Hypothesis testing is done by multivariate analysis carried out through the WarpPLS program. Data analysis through partial Least Square (PLS) is done through two stages, namely: First, Assessing the outer model or measurement model. Second, assess the inner model or structural model. The results showed that there was a positive and not significant effect between Openness on employee organizational citizenship behavior, There was a positive and significant effect between Conscientiousness on organizational citizenship behavior of employees, There was a positive and insignificant effect between Extraversion on organizational citizenship behavior of employees, There was an influence a positive and significant relationship between Agreeableness on organizational citizenship behavior of employees, There is a positive and significant influence between Neuroticism on organizational citizenship behavior of employees, There is a positive and insignificant effect between Openness on employee performance, There is a positive and insignificant effect between Conscientiousness on performance employees, There is a positive and significant influence between Extraversion on employee performance, There is a positive and significant effect between Agreeabl eness on employee performance, There is a positive and insignificant influence between Neuroticism on employee performance, There is a positive and not significant effect between organizational citizenship behavior on employee performance of PT BPD Kaltim Kaltara Samarinda Branch.
\end{abstract}

Keywords: Openness, Conscientiousness, Extraversion, Agreeableness, Neuroticism, Organizational Citizenship Behavior, Performance.

\section{Introduction}

Personality is important in predicting OCB employee behavior and it is important to use it in the employee selection process. So that it can target prospective employees with certain traits, especially on traits that can increase OCB (Elanain, 2007). Simply put, organizational citizenship behavior can be in the form of employees who help solve the problems of others who are outside the authority and responsibilities of their jobs, senior employees who have experience providing training to new employees outside working hours, or employees who actively participate in team meetings when discussing improvements or housekeeping at work. 
Saeedy (2015) states that personality can also be one of the predictors in evaluating how much OCB is done by employees to be able to retain the best employees owned by the organization. So it is important for organizations to know the personality of each employee.

Companies must believe that to be able to achieve excellence, companies must be able to strive for the highest performance of individuals by fostering positive behavior in employees in order to improve performance.

Youshan \& Hassan (2015) stated that five personality dimensions possessed by employees can affect their performance. employees who have high values in their personality dimensions tend to produce good performance and are more concerned with the interests of the company.

Robbins \& Judge (2015:235), which states that: facts show that organizations that have employees who have good OCB, will have better performance than other organizations. The development of innovations that are generated and flexibility in the organizational environment are the focus of attention and emphasis that stimulates the members of the organization to voluntarily display extra-role behavior that is included in interpersonal skills. These skills can only be displayed by individuals who care about other individuals and try to show their best far beyond the prerequisites in their work. Work productivity is generally expressed in terms of effectiveness and efficiency. The effectiveness of teamwork is determined by the ability of team members to communicate, cooperate, share information and tolerate differences that exist in the team. In other words the individual displays extra-role behavior.

Extra-role behavior in organizations is also known as organizational citizenship behavior (OCB), and people who display OCB behavior are called good employees. Examples of behavior that are included in the OCB group are assisting coworkers, volunteering to do extra activities at work, avoiding conflicts with coworkers, protecting organizational property, respecting regulations applicable in the organization, tolerance to less than ideal / pleasant situations at work, giving advice constructs at work, and doesn't waste time at work.

Empirically the influence of OCB with performance has been widely proven. Research conducted by Bush \& Jiao (2011) employees who have high performance and low performance are influenced by OCB. Shokrkon (2009), job satisfaction and OCB influence in improving employee performance. The results of research conducted by Palagia (2012), concluded that job satisfaction partially has a positive and significant effect on performance. Research Jahangir (2004), Job satisfaction has been found to have a positive relationship with job performance and OCB which can be interpreted as job satisfaction has a positive effect on performance and OCB.

The phenomenon of the problem in this study is also known through the comparison of empirical tests of relationships between variables according to Bush \& Jiao (2011), Bonaparte (2008), Martinez (2013), stating that organizational citizenship behavior has a significant effect on performance, while research conducted by Ali \& Zarei (2012), Aslam \& Afzal (2010) states that organizational citizenship behavior has no significant effect on performance.

Performance is the result of work achieved by someone in carrying out the tasks that have been given. An increase in employee performance at the company is needed so that the objectives of the company can be achieved. Employees who have personalities that match their jobs tend to produce high performance, this is because the different personalities of each employee will produce different performance (Mahlamaki, 2012).

A company's performance will improve if there is cooperation and a good relationship between each employee. In a study carried out by Basu et al. (2017) states that OCB can affect employee performance. The existence of OCB behavior that is raised by employees will tend to increase the ability among colleagues and managers in planning, so that it will produce high 
performance and the objectives of the organization can be achieved well. By increasing the performance of employees, it will improve the performance of the company.

Robbins (2006) performance is a result achieved by employees in their work according to certain criteria that apply to a job. Al-Mahasneh (2015) which states OCB influences employee performance. Employees who have high OCB behavior will tend to be creative so that it can increase motivation at work and will have an impact on improving the work performance of these employees. Robbins (2009 : 9) performance is the result of quality and quantity of work achieved by an employee in carrying out their duties in accordance with the responsibilities that have been given.

Thus, performance is a form of success or failure of individuals or companies in carrying out the work that has been determined. The difference in the work results of each employee is due to differences in individual characteristics and different situations. Performance in carrying out its functions does not stand alone but relates to individual factors, organizations, and the external environment. If a group of employees has a good performance, it will have an impact on good company performance as well.

\section{Underlying Theory}

\section{The Big Five Personality on Organizational Citizenship Behavior}

Organ et al (2006) categorize the factors that influence OCB as individual differences, attitudes towards work, and contextual factors, where personality is included as a factor of differences between individuals. Personality is considered as one of the factors that can significantly influence OCB.

According to Connect and Iring (2014) personality is the uniqueness that distinguishes individuals from other individuals. Which is the difference in each individual is a predictor who plays an important role in employees so that employees will show their OCB. Purba and Seniati (2004) personality is an intrinsic thing that is in a person and is difficult to change, so it has a great influence in maintaining OCB.

The theory of personality models used in this study is Big Five Personality. Robbins and Judge (2008) state that the Big Five Personality is the five basic dimensions that cover the majority of personalities in humans. Five dimensions can predict well how individual behavior in their daily lives,

Based on the explanation above, one of the factors that influence OCB behavior is the personality of the individual. Personality in individuals plays an important role in OCB. This is consistent with the results of Elanain's (2007) research that personality is important in predicting employee OCB behavior and it is important to use it in the employee selection process. So that it can target prospective employees with certain traits, especially on traits that can enhance OCB.

The organization is considered important to find out what type of personality employees have the most possibility to have OCB at work, as a basis for making decisions in retaining existing employees or selecting prospective employees. This is consistent with Saeedy's research (2015)which states that personality can also be one of the predictors in evaluating how much OCB is done by employees to be able to retain the best employees owned by the organization. So it is important for organizations to know the personality of each employee.

Employees who have dimensions of personality openness, conscientiousness, extroversion, agreeablesness, and high emotional stability then he will like and easy to socialize, gentle, conscientious, responsible, not emotional, creative and relaxed so that he will have a high OCB too (Ingarianti, 2014); (Kappagoda, 2013); (Fitriyani, 2013). 


\section{Research Hypothesis}

a. There is a positive and significant influence between Openness on organizational citizenship behavior of employees of PT BPD Kaltim Kaltara Samarinda Branch

b. There is a positive and significant influence between Conscientiousness on organizational citizenship behavior of employees of PT BPD Kaltim Kaltara Samarinda Branch

c. There is a positive and significant influence between Extraversion on organizational citizenship behavior of employees of PT BPD Kaltim Kaltara Samarinda Branch

d. There is a positive and significant influence between Agreeableness on organizational citizenship behavior of employees of PT BPD Kaltim Kaltara Samarinda Branch

$e$. There is a positive and significant influence between Neuroticism on organizational citizenship behavior of employees of PT BPD Kaltim Kaltara Samarinda Branch

\section{The Big Five Personality on Performance}

Personality is a good predictor for measuring performance in employees in situations where management's expectations so that employees can display the performance clearly. As stated by Griffin (in Saefullah, 2006:219) the dimensions of The Big Five Personality in the form of openness, conscientiousness, extroversion, agreeablesness, and emotional stability explain that basically these personalities are found in every individual and underlie each other and encompass most of them significant variation in human personality.

Youshan and Hassan (2015) stated that five personality dimensions possessed by employees can affect their performance. employees who have high values in their personality dimensions tend to produce good performance and are more oriented towards the interests of the organization rather than themselves. Every organization needs to understand the personality possessed by each employee, because this is important in planning employee positions at work.

Which if the higher the value of the five dimensions of personality in individuals, it will tend to cause high performance. Employees who have personalities that match their jobs tend to produce high performance, this is because the different personalities of each employee will produce different performance (Mahlamaki et al., 2012).

\section{Research Hypothesis}

a. There is a positive and significant influence between Openness on the performance of employees of PT BPD Kaltim Kaltara Samarinda Branch

b. There is a positive and significant effect between Conscientiousness on the performance of employees of PT BPD Kaltim Kaltara Samarinda Branch

c. There is a positive and significant influence between Extraversion on the performance of employees of PT BPD Kaltim Kaltara Samarinda Branch

d. There is a positive and significant influence between Agreeableness on the performance of employees of PT BPD Kaltim Kaltara Samarinda Branch

e. There is a positive and significant influence between Neuroticism on the performance of employees of PT BPD Kaltim Kaltara Samarinda Branch

\section{Organizational Citizenship Behavior on Performance}

OCB is a term used to identify employee behavior. OCB is a form of employee contribution that goes deeper than the jobdesk provided by the organization without obtaining formal rewards. OCB includes behaviors such as helping co-workers, volunteering for other co-workers' extra duties, adhering to rules and procedures at work. 
International Journal of Economics, Business and Accounting Research (IJEBAR)

Peer Reviewed - International Journal

Vol-4, Issue-1, 2020 (IJEBAR)

E-ISSN: 2614-1280 P-ISSN 2622-4771

https://jurnal.stie-aas.ac.id/index.php/IJEBAR

According to Podsakoff et al (2000:544) the benefits of OCB are that it can increase coworker productivity, increase manager productivity, save resources owned by management and organization, can be an effective means of coordinating work groups, able to increase the organization's ability to attract and retain employees best and improve organizational performance stability.

Basu et al. (2017) states that OCB can affect employee performance. The existence of OCB behavior that is raised by employees will tend to increase the ability among colleagues and managers in planning, so that it will produce high performance and the objectives of the organization can be achieved well.

Employees who have OCB behavior tend to be creative employees so that the resulting performance will increase. This is in accordance with Al-Mahasneh (2015) which states that OCB affects employee performance. Employees who have high OCB behavior will tend to be creative so they can increase motivation at work, so that it will have an impact on improving the work performance of these employees.

\section{Research Hypothesis}

There is a positive and significant effect between organizational citizenship behavior on the performance of employees of PT BPD Kaltim Kaltara Samarinda Branch

\section{Discussion}

\section{Research Model Using Partial Least Square (PLS)}

In this study, the data obtained were analyzed using a partial least square (PLS) analysis tool with the following results:

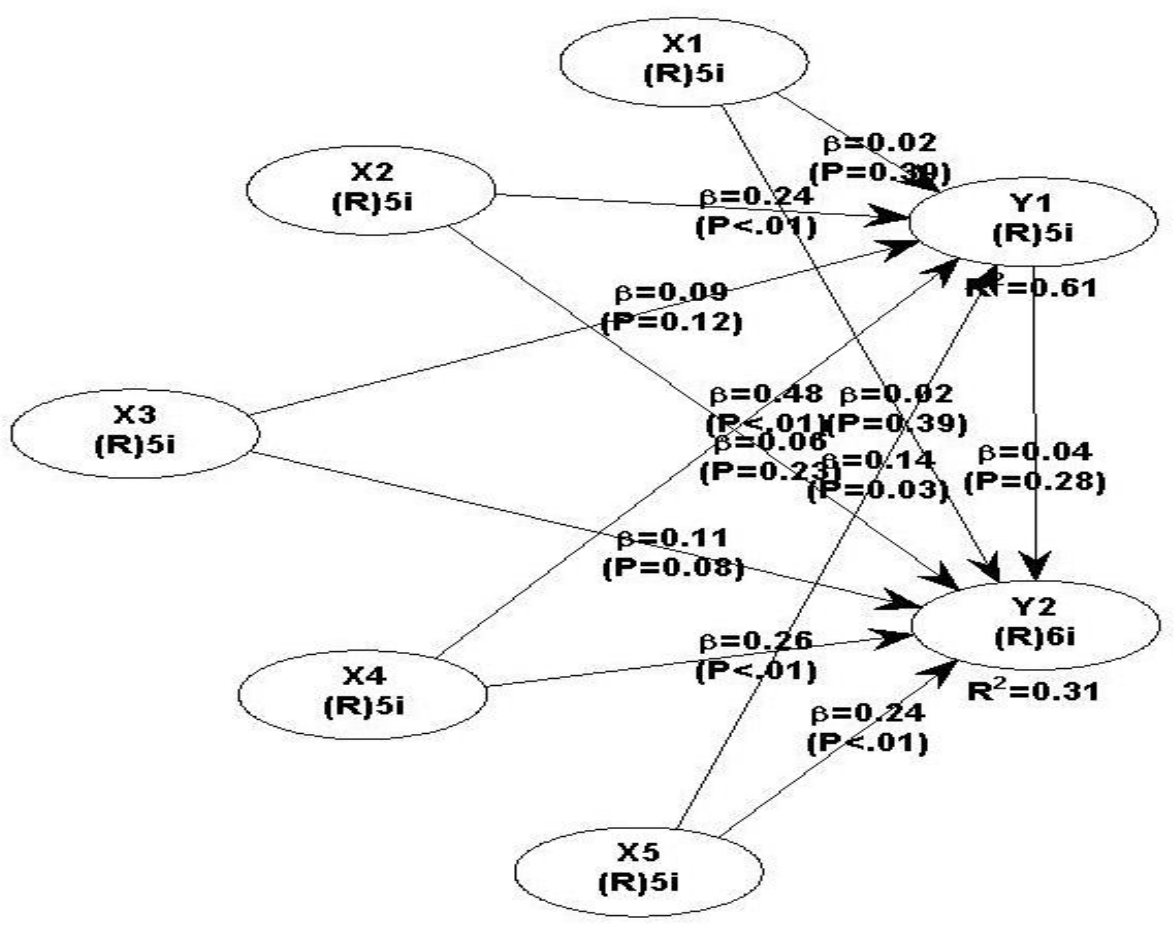

Gambar:

Early Research Model 
International Journal of Economics, Business and Accounting Research (IJEBAR)

Peer Reviewed - International Journal

Vol-4, Issue-1, 2020 (IJEBAR)

E-ISSN: 2614-1280 P-ISSN 2622-4771

https://jurnal.stie-aas.ac.id/index.php/IJEBAR

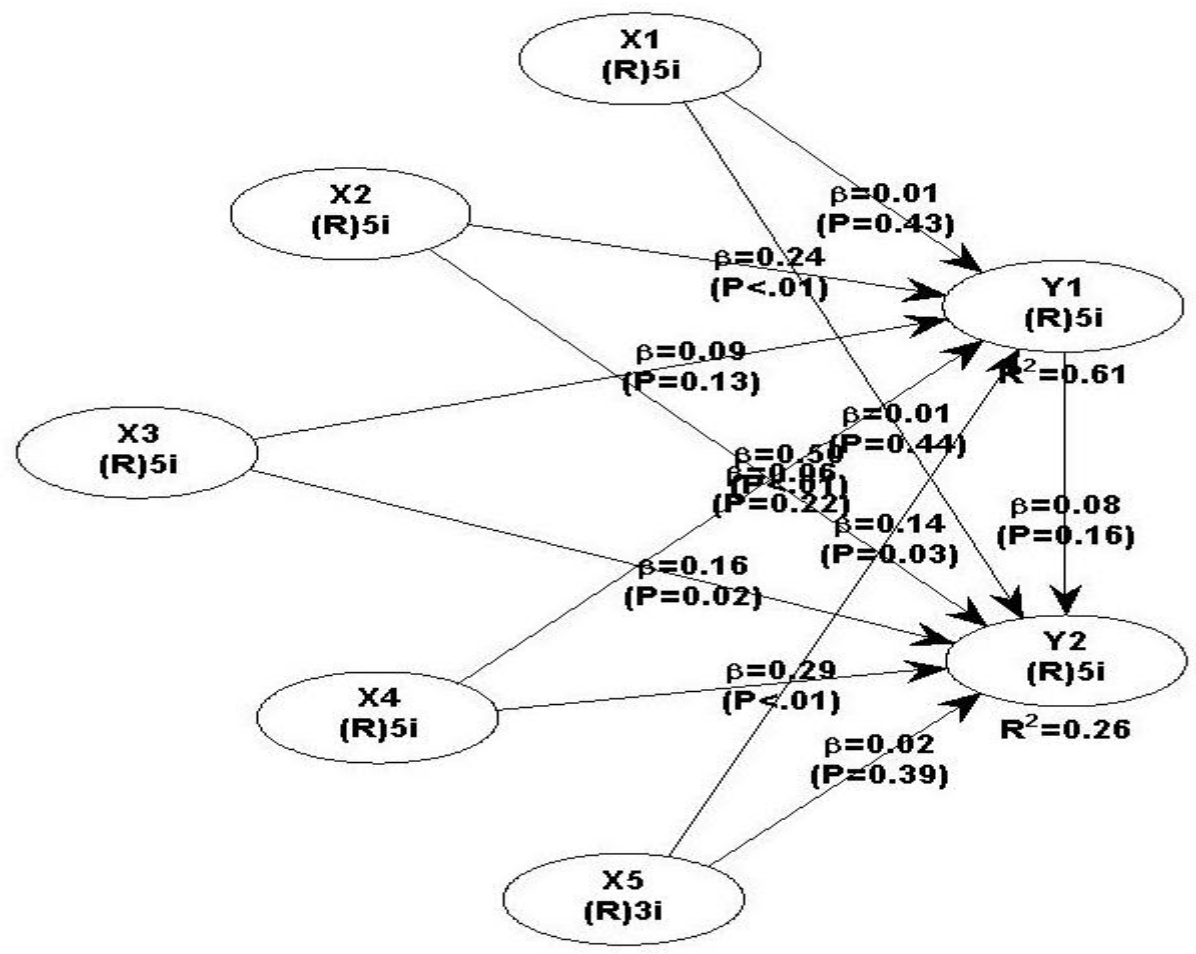

Gambar:

New Research Model

\section{Discriminant Validity}

Table: Average Variance Extracted \& Root AVE

\begin{tabular}{|c|c|c|c|}
\hline & AVE & $\sqrt{A V E}$ & Information \\
\hline X1 & 0,617 & 0,785 & Valid \\
\hline X2 & 0,457 & 0,676 & Valid \\
\hline X3 & 0,478 & 0,691 & Valid \\
\hline X4 & 0,442 & 0,664 & Valid \\
\hline X5 & 0,683 & 0,826 & Valid \\
\hline Y1 & 0,509 & 0,713 & Valid \\
\hline Y2 & 0,594 & 0,770 & Valid \\
\hline
\end{tabular}

Source: WarpPLS Output, 2020

\section{Composite Reliability}

To know the reliability of all constructs can be seen from the value of composite reliability. The construct is reliable if the composite reliability value is above 0.70 . The output results show all constructs on the variables of openness, conscientiousness, extraversion, organizational citizenship behavior and employee performance, reliable because of composite reliability values> 0.70 , with the following table description:

Table: Composite Reliability

\begin{tabular}{|c|c|}
\hline & Composite Reliability \\
\hline Openness & 0,889 \\
\hline Conscientiousness & 0,807 \\
\hline
\end{tabular}

International Journal of Economics, Business and Accounting Research (IJEBAR) 
International Journal of Economics, Business and Accounting Research (IJEBAR)

Peer Reviewed - International Journal

Vol-4, Issue-1, 2020 (IJEBAR)

E-ISSN: 2614-1280 P-ISSN 2622-4771

https://jurnal.stie-aas.ac.id/index.php/IJEBAR

\begin{tabular}{|c|c|}
\hline Extraversion & 0,820 \\
\hline Agreeableness & 0,797 \\
\hline Neuroticism & 0,866 \\
\hline Organizational citizenship behavior & 0,838 \\
\hline Performance & 0,877 \\
\hline
\end{tabular}

Source: WarpPLS Output, 2020

\section{Measurement Model or Inner Model \\ Goodness of Fit Model Check}

Examination of the model can be seen from the value of R2 (R-square). This means that the model can explain phenomena or variations in organizational citizenship behavior can be explained by the variables openness, conscientiousness, extraversion, agreeableness, neuroticism by 61.40 percent $(0.614 \times 100 \%)$ while the rest is explained by variations in other variables outside of the research model by 38.60 percent $(100 \%-61.40 \%)$. The phenomenon or variations in employee performance can be explained by variables of openness, conscientiousness, extraversion, agreeableness, neuroticism and organizational citizenship behavior by 26.20 percent $(0.262 \times 100 \%)$ while the rest are explained by other variable variations outside of the research model by 73.80 percent $(100 \%-26.20 \%)$

\section{t-test}

In the WarpPLS program is done by t-test on each track. The test results can be seen in the table below:

Table: Results for Inner Weights

\begin{tabular}{|c|c|c|c|}
\hline Influence between Variables & $\begin{array}{l}\text { Original sample } \\
\text { estimate }\end{array}$ & P Values & Information \\
\hline $\begin{array}{l}\text { Openness to organizational } \\
\text { citizenship behavior }\end{array}$ & 0,014 & 0,427 & $\begin{array}{l}\text { Positive not } \\
\text { significant }\end{array}$ \\
\hline $\begin{array}{c}\text { Conscientiousness to } \\
\text { organizational citizenship } \\
\text { behavior }\end{array}$ & 0,241 & 0,001 & $\begin{array}{l}\text { Positive } \\
\text { significant }\end{array}$ \\
\hline $\begin{array}{c}\text { Extraversion to } \\
\text { organizational citizenship } \\
\text { behavior }\end{array}$ & 0,087 & 0,131 & $\begin{array}{l}\text { Positive not } \\
\text { significant }\end{array}$ \\
\hline $\begin{array}{c}\text { Agreeableness to } \\
\text { organizational citizenship } \\
\text { behavior }\end{array}$ & 0,500 & 0,001 & $\begin{array}{l}\text { Positive } \\
\text { significant }\end{array}$ \\
\hline $\begin{array}{l}\text { Neuroticism to organizational } \\
\text { citizenship behavior }\end{array}$ & 0,143 & 0,031 & $\begin{array}{l}\text { Positive } \\
\text { significant }\end{array}$ \\
\hline Openness to performance & 0,013 & 0,436 & $\begin{array}{l}\text { Positive not } \\
\text { significant }\end{array}$ \\
\hline $\begin{array}{c}\text { Conscientiousness to } \\
\text { performance }\end{array}$ & 0,059 & 0,223 & $\begin{array}{c}\text { Positive not } \\
\text { significant }\end{array}$ \\
\hline Extraversion to performance & 0,163 & 0,017 & $\begin{array}{l}\text { Positive } \\
\text { significant }\end{array}$ \\
\hline $\begin{array}{l}\text { Agreeableness to } \\
\text { performance }\end{array}$ & 0,294 & 0,001 & $\begin{array}{l}\text { Positive } \\
\text { significant }\end{array}$ \\
\hline
\end{tabular}

International Journal of Economics, Business and Accounting Research (IJEBAR) 
International Journal of Economics, Business and Accounting Research (IJEBAR)

Peer Reviewed - International Journal

Vol-4, Issue-1, 2020 (IJEBAR)

E-ISSN: 2614-1280 P-ISSN 2622-4771

https://jurnal.stie-aas.ac.id/index.php/IJEBAR

\begin{tabular}{|c|c|c|c|}
\hline Influence between Variables & $\begin{array}{c}\text { Original sample } \\
\text { estimate }\end{array}$ & P Values & Information \\
\hline Neuroticism to performance & 0,022 & 0,391 & $\begin{array}{c}\text { Positive not } \\
\text { significant }\end{array}$ \\
\hline $\begin{array}{c}\text { organizational citizenship } \\
\text { behavior to performance }\end{array}$ & 0,077 & 0,160 & $\begin{array}{c}\text { Positive not } \\
\text { significant }\end{array}$ \\
\hline
\end{tabular}

Source: WarpPLS Output, 2020

Based on the table, it can be seen the positive influence and the level of significance of each variable, if T-Statistic> 1.96 means that exogenous variables have a significant influence on endogenous variables and if T-Statistic <1.96, exogenous variables give insignificant influence on endogenous variables with an explanation as following:

a. There is a positive and insignificant influence between Openness on organizational citizenship behavior of employees of PT BPD Kaltim Kaltara Samarinda Branch, because it has a coefficient value of 0.014 and p-value $0.427>0.05$.

b. There is a positive and significant influence between Conscientiousness on organizational citizenship behavior of employees of PT BPD Kaltim Kaltara Samarinda Branch, because it has a coefficient value of 0.241 and p-value of $0.001<0.05$.

c. There is a positive and insignificant influence between Extraversion on organizational citizenship behavior of employees of PT BPD Kaltim Kaltara Samarinda Branch, because it has a coefficient value of 0.087 and p-value $0.131>0.05$.

d. There is a positive and significant influence between Agreeableness on organizational citizenship behavior of employees of PT BPD Kaltim Kaltara Samarinda Branch, because it has a coefficient value of 0.500 and a p-value of $0.001<0.05$.

e. There is a positive and significant influence between Neuroticism on organizational citizenship behavior of employees of PT BPD Kaltim Kaltara Samarinda Branch, because it has a coefficient value of 0.143 and a p-value of $0.031<0.05$.

f. There is a positive and insignificant influence between Openness on the performance of employees of PT BPD Kaltim Kaltara Samarinda Branch, because it has a coefficient value of 0.013 and p-value of $0.436>0.05$.

g. There is a positive and insignificant influence between Conscientiousness on the performance of employees of PT BPD Kaltim Kaltara Samarinda Branch, because it has a coefficient value of 0.059 and p-value $0.223>0.05$.

$\mathrm{h}$. There is a positive and significant influence between Extraversion on the performance of employees of PT BPD Kaltim Kaltara Samarinda Branch, because it has a coefficient value of 0.163 and a $\mathrm{p}$-value of $0.017<0.05$.

i. There is a positive and significant influence between Agreeableness on the performance of employees of PT BPD Kaltim Kaltara Samarinda Branch, because it has a coefficient value of 0.294 and a p-value of $0.001<0.05$.

j. There is a positive and insignificant influence between Neuroticism on the performance of employees of PT BPD Kaltim Kaltara Samarinda Branch, because it has a coefficient value of 0.022 and p-value of $0.391>0.05$.

k. There is a positive and insignificant influence between organizational citizenship behavior on the performance of employees of PT BPD Kaltim Kaltara Samarinda Branch, because it has a coefficient value of 0.077 and a p-value of $0.160>0.05$.

\section{Conclusions and Recommendations}




\section{Conclusion}

Based on the results of the analysis and discussion it can be concluded as follows:

a. There is a positive and insignificant influence between Openness on organizational citizenship behavior of employees of PT BPD Kaltim Kaltara Samarinda Branch.

b. There is a positive and significant influence between Conscientiousness on organizational citizenship behavior of employees of PT BPD Kaltim Kaltara Samarinda Branch.

c. There is a positive and insignificant influence between Extraversion on organizational citizenship behavior of employees of PT BPD Kaltim Kaltara Samarinda Branch.

d. There is a positive and significant influence between Agreeableness on organizational citizenship behavior of employees of PT BPD Kaltim Kaltara Samarinda Branch.

e. There is a positive and significant influence between Neuroticism on organizational citizenship behavior of employees of PT BPD Kaltim Kaltara Samarinda Branch.

f. There is a positive and insignificant influence between Openness on the performance of employees of PT BPD Kaltim Kaltara Samarinda Branch.

g. There is a positive and insignificant influence between Conscientiousness on the performance of employees of PT BPD Kaltim Kaltara Samarinda Branch.

h. There is a positive and significant influence between Extraversion on the performance of employees of PT BPD Kaltim Kaltara Samarinda Branch.

i. There is a positive and significant influence between Agreeableness on the performance of employees of PT BPD Kaltim Kaltara Samarinda Branch.

j. There is a positive and insignificant influence between Neuroticism on the performance of employees of PT BPD Kaltim Kaltara Samarinda Branch.

k. There is a positive and insignificant influence between organizational citizenship behavior on the performance of employees of PT BPD Kaltim Kaltara Samarinda Branch.

\section{Suggestion}

Based on the conclusions above, the suggestions in this study are as follows:

a. It is very important to maintain the personality of employees to improve the performance of employees of PT BPD Kaltim Kaltara Samarinda Branch, another thing that must be considered is to increase employee loyalty to work and organization by listening to the problems and complaints faced by employees of PT BPD Kaltim Kaltara Branch Samarinda.

b. Increase awareness of employees of PT BPD Kaltim Kaltara Samarinda Branch in order to have a very important role in advancing the organization. PT BPD Kaltim Kaltara Samarinda Branch should create a pleasant working atmosphere that will make employees feel at home working in the long run.

c. For further researchers who will examine expected to be able to examine with different variables such as work engagement, employee turnover, job satisfaction and work ethic.

d. For the next researcher, it is hoped that they will examine as closely as possible the factors that influence organizational citizenship behavior and the performance of PT BPD Kaltim Kaltara Samarinda Branch.

\section{References}

Al-Mahasneh, M. A. (2015). The impact of Organizational Citizenship Behavior on Job Performance at Greater Amman Municipality. European Journal of Business and Management, 108-118.

Ali Rastgar, A., \& Zarei, A. (2012). The Link Between Workplace Spirituality , Organizational 
International Journal of Economics, Business and Accounting Research (IJEBAR)

Peer Reviewed - International Journal

Vol-4, Issue-1, 2020 (IJEBAR)

E-ISSN: 2614-1280 P-ISSN 2622-4771

https://jurnal.stie-aas.ac.id/index.php/IJEBAR

Citizenship Behavior And Job Performance In Iran. Journal of Economics and Management, 1(6), 51-67.

Aslam, M. K., \& Afzal, H. (2010). Correlation between Antecedents of Organizational Citizenship Behavior and Organizations Performance In Contemporary Pakistani Organizations. Interdisciplinary Journal Of Contemporary Research In Business, 1(11), 178-190.

Basu, E., Pradhan, R. K., \& Tewari, H. R. (2017). Impact of organizational citizenship behavior on job performance in Indian healthcare industries: The mediating role of social capital. International Journal of Productivity and Performance Management, 780-796.

Bonaparte, W. (2008). The Impact Of Organizational Citizenship Behavior And Organizational Commitmnt On Organizational Performance. School of Business and Entrepreneurship Nova Southeastern University.

Bush, M. S., \& Jiao, C. (2011). Including Organizational Citizenship Behavior in Performance Evaluations: An Investigation of Employee Reactions. International Journal of Business and Management, 6(10), 50-58.

Elanain, H. A. (2007). Relationship between Personality and Organizational Citizenship Behavior: Does Personality Influence Employee Citizenship? International Review of Business Research Papers, 3(4), 31-43.

Fitriyani, W. (2013). Pengaruh Kepribadian dan Job Embeddedness Terhadap Organizational Citizenship Behavior (OCB) Pada Karyawan PT. Hadji Kalla Makassar.

Jahangir, N. (2004). Organizational citizenship behavior: Its nature and antecedents. BRAC University Journal, 1, 75-85.

Kappagoda, U. W. M. R. S. (2013). The Impact of Five Factor Model of Personality on Organizational Citizenship Behavior of Non-Managerial Employees in the Banking Sector in Sri Lanka. International Journal of Research in Computer Aplication and Management, $3,168-173$.

Mahlamäki, T., Uusitalo, O., \& Ojala, M. (2012). the Influence of Personality on the Job Performance of Key Account Managers. Human Capital Analysis Group.

Martinez, R. N. (2013). Impact of team citizenship behaviors on performance in women's sports teams. Dissertation Abstracts International: Section B: The Sciences and Engineering, 74.

Organ, D.W., Podsakoff, P.M., \&MacKanzie S, P. (2006). Organizational Citizenship Behavior: Its Nature, Incidents, and Consequences. London: Sage Publications.

Palagia, N. dan Y. (2012). Remunerasi,Motivasi, dan Kepuasan Kerja Terhadap Kinerja Pegawai Pada Kantor Pajak. E-Journal Program Pascasarjana Universitas Hasanuddin.

Podsakoff et al. (2000). Organizational Citizenship Behavior: A Critical Review of the Theoretical and Empirical Literature and Suggestions for Future Research. Journal of Management, 26(3), 544.

Purba, D. E., and Seniati, A. N. (2004). Pengaruh kepribadian dan komitment organisasi terhadap organizational citizenship behavior. Sosial Humaniora, 8(3), 105-111.

Robbins, Stephen P,; Judge, T. A. (2008). Perilaku Organisasi. Jakarta: Salemba Empat.

Robbins, Stephen P,; Judge, T. A. (2015). Perilaku Organisasi (15th ed.). Jakarta: Salemba Empat.

Robbins, S. (2006). Perilaku Organisasi. Jakarta: PT INDEKS Kelompok Gramedia.

Robbins, S. P. (2009). Perilaku Organisasi (Buku 1). Jakarta: Salemba Empat.

Saeedy, S., \& Ali Rastgar, A. (2015). Study of the Role of Personality Factors in Organizational Citizenship Behaviors. Trends Journal of Sciences Research, 2(2), 50-55.

Saefullah, K. dan E. T. S. (2006). Pengantar Manajemen. Jakarta: Prenada Media. 
International Journal of Economics, Business and Accounting Research (IJEBAR)

Peer Reviewed - International Journal

Vol-4, Issue-1, 2020 (IJEBAR)

E-ISSN: 2614-1280 P-ISSN 2622-4771

https://jurnal.stie-aas.ac.id/index.php/IJEBAR

Sambung, R., \& I. (2014). Pengaruh Kepribadian Terhadap Organizational Citizenship Behaviour dengan Komitmen Organizational sebagai Variabel Intervening. Manajemen Dan Akuntansi, 1-16.

Shokrkon, H. and A. N. (2009). The Relationship with Organizational Citizenship Behavior and Job Performance in Ahvas Factory Workers. Journal of Education and Psychology, 3(2), $39-52$.

Tri Muji Ingarianti. (2014). Hubungan Antara Kepribadian (The Big Five Factor Personality) dengan Organizational Citizenship Behavior pada Karyawan.

Youshan, B., \& Hassan, Z. (2015). The Effect of Employees Personality on Organizational Performance: Study on Insurance Company. International Journal of Accounting and Business Management, 4(2), 187-196. 